\title{
Effect of milking frequency on the behavior and productivity of lactating dairy cows
}

\author{
K. D. Hart, * B. W. McBride, $†$ T. F. Duffield, $\ddagger$ and T. J. DeVries*1 \\ *Department of Animal and Poultry Science, University of Guelph, Kemptville Campus, 830 Prescott Street, Kemptville, ON, K0G 1J0, Canada \\ †Department of Animal and Poultry Science, University of Guelph, 50 Stone Road East, Guelph, ON, N1G 2W1, Canada \\ ‡Department of Population Medicine, University of Guelph, 50 Stone Road East, Guelph, ON, N1G 2W1, Canada
}

\section{ABSTRACT}

The objective of this study was to determine the effect of milking frequency on the behavioral patterns and productivity of lactating dairy cows. Twelve freestall-housed, lactating Holstein dairy cows (7 primiparous and 5 multiparous) were exposed to each of 2 treatments (over 21-d periods) in a replicated crossover design. Treatments were milking frequency of $2 \times / d$ (at 0600 and $1800 \mathrm{~h}$ ) or $3 \times / \mathrm{d}$ (at 0600, 1400, and 2200 h). Milk production, feeding, lying, and rumination behavior were monitored for each animal for the last $7 \mathrm{~d}$ of each treatment period. Milk samples were collected for the last $3 \mathrm{~d}$ of each period for milk component analysis. The results indicated that cows milked $3 \times / \mathrm{d}$ produced $2.9 \mathrm{~kg} / \mathrm{d}$ more milk than those milked $2 \times /$ d. Primiparous cows consumed $3.9 \mathrm{~kg} / \mathrm{d}$ less dry matter (DM) than did multiparous cows. The extra time $(14.6 \mathrm{~min} / \mathrm{d})$ required for milking $3 \times / \mathrm{d}$ altered the distribution of cow behavioral activity throughout the day. Although this did not affect total daily lying or rumination time, we observed a tendency for cows milked $2 \times / \mathrm{d}$ to spend less time (224.6 vs. $237.5 \mathrm{~min} / \mathrm{d}$ ) feeding and, thus, those cows tended to consume their feed at a faster rate (0.13 vs. $0.12 \mathrm{~kg}$ of $\mathrm{DM} / \mathrm{min})$ than cows milked $3 \times /$ d. For multiparous cows, the increase in feeding activity was facilitated through having longer (40.1 vs. $36.8 \mathrm{~min} / \mathrm{meal}$ ) and numerically larger meals ( 4.8 vs. $4.6 \mathrm{~kg}$ of $\mathrm{DM} /$ meal) when milked $3 \times / \mathrm{d}$. Alternatively, primiparous cows consumed smaller (2.9 vs. $3.2 \mathrm{~kg}$ of DM/meal) and more frequent meals (9.1 vs. 7.7 meals/d) throughout the day when milked $3 \times / d$, resulting in a tendency for greater DM intake (24.7 vs. $23.6 \mathrm{~kg} / \mathrm{d}$ ) compared with primiparous cows milked $2 \times /$ d. These results indicate that under $3 \times / d$ milking schedules, primiparous cows will positively adjust their feeding behavior to achieve similar production increases as multiparous cows. In summary, milking $3 \times / d$ can

Received March 6, 2013.

Accepted July 18, 2013.

${ }^{1}$ Corresponding author: tdevries@uoguelph.ca be used to improve production; however, greater milking frequency elicits varying effects on the behavior of primiparous and multiparous cows, suggesting that grouping and management of cows based on parity may be beneficial.

Key words: dairy cow, milking frequency, behavior

\section{INTRODUCTION}

Increased milk yield and improved production efficiency can be achieved by milking cows more frequently (Erdman and Varner, 1995; Cabrera et al., 2010). Milking frequencies greater than $2 \times / \mathrm{d}$ can increase milk yield by 10.4 to $21 \%$ (Bar-Peled et al., 1995; Klei et al., 1997; Smith et al., 2002), and greater milking frequencies in early lactation can increase milk yield persistency (Bar-Peled et al., 1995; Hale et al., 2003; Dahl et al., 2004). Cows milked $3 \times / d$ have shown significantly decreased milk fat percentages compared with those milked $2 \times /$ d (Sapru et al., 1997; Smith et al., 2002); however, milk fat yield is not affected by milking frequency (Barnes et al., 1990). Milking $3 \times / d$ is associated with small increases in FCM and ECM (Barnes et al., 1990; Smith et al., 2002) and greater technical efficiency on farm (Cabrera et al., 2010). Increased milking frequency has also shown a reduction in SCC and a tendency for reduced SCC throughout lactation (Smith et al., 2002; Dahl et al., 2004).

Increased milk production comes at a significant energy cost (Bar-Peled et al., 1995); therefore, increased milking frequency must be supported by a greater plane of nutrition (Varner et al., 2002). Unfortunately, the time required for extra milkings to occur at greater milking frequencies can greatly reduce the time available for other activities, such as feeding, rumination, and lying behaviors. These behaviors are critical for the maintenance of energy balance, efficient digestion, and cow health and welfare, and to allow the cow to meet her production demands. Because lying has been shown to have priority over feeding when cows have been simultaneously deprived of the ability to do both (Metz, 1985), and return from milking is a significant stimulus 
for cows to feed (DeVries et al., 2003a; DeVries and von Keyserlingk, 2005), feeding behavior patterns are likely to be altered when milking frequency is increased. Greater time spent milking has been associated with less time feeding (Gomez and Cook, 2010), but little research has been done to directly examine the effect of milking frequency on feeding behavior patterns and how dairy cows alter their behavioral patterns to compensate for the restrictions imposed by such a management practice. O'Driscoll et al. (2010a,b) studied the effect of milking $1 \times$ or $2 \times / d$ on the behavior of pastured dairy cattle. These researchers noted that, even though milking $2 \times$ versus $1 \times / d$ altered the distribution of grazing and lying behavior throughout the day, cows were able to adjust their behavior patterns to maintain similar durations of grazing and lying behavior. It is unknown, however, if dairy cattle milked more frequently than $2 \times / d$ and housed and fed indoors would be able to similarly adjust their behavior patterns to compensate for the extra time required for milking. To our knowledge, no studies to date have compared the behavioral responses of dairy cows milked $3 \times / d$ versus $2 \times / d$.

Thus, the objective of this study was to determine the effect of milking frequency on the behavioral patterns and productivity of lactating dairy cows. We hypothesized that increasing milking frequency from $2 \times$ to $3 \times / d$ would result in increased feeding activity, particularly after milking, resulting in a more uniform distribution of feeding activity throughout the day, and thus alter the distribution of lying and ruminating behavior patterns throughout the day. Given reports of greater production response in primiparous cows to increased milking frequency (Gisi et al., 1986; Barnes et al., 1990), we also hypothesized that these behavioral effects would be magnified in primiparous cows.

\section{MATERIALS AND METHODS}

\section{Animals and Housing}

Twelve lactating Holstein dairy cows, including 7 primiparous and 5 multiparous (parity $=3.0 \pm 1.0$; mean $\pm \mathrm{SD}$ ), were used in this study. The animals were $149.5 \pm 31.3$ DIM and were producing $37.6 \pm 8.1 \mathrm{~kg}$ of milk at the beginning of the trial. The cows were housed 6 at a time in a freestall research pen located at the University of Guelph, Kemptville Campus Dairy Education and Innovation Centre (Kemptville, ON, Canada). Cows had access to 6 freestalls with waterbeds (DCC Waterbeds, Advanced Comfort Technology Inc., Reedsburg, WI). The waterbeds were topped with wood shavings, and bedding was replaced as needed. Manure was manually scraped to within reach of the alley scrapers $2 \times / \mathrm{d}$ at 0600 and $1800 \mathrm{~h}$. The experiment was conducted from January 27 to April 27, 2012. The average environmental temperature during the experimental period was $1.5 \pm 7.3^{\circ} \mathrm{C}$. Use of cows and experimental procedures were approved by the University of Guelph's Animal Care Committee. Cows were managed according to the guidelines set forth by the Canadian Council on Animal Care (2009).

\section{Experimental Design}

The number of animals required per treatment was determined through sample size and power analysis (Morris, 1999) for the primary outcome variables, including behavior, DMI, sorting, and milk production and composition. Cows were divided into 2 groups of 6 , which were balanced according to DIM, milk production, and average parity. Within each group, cows were randomly exposed to each of 2 treatments in a replicated crossover design (with groups replicated over time), with 21-d treatment periods. The treatments were milking frequency: (1) $2 \times / \mathrm{d}$ (at 0600 and $1800 \mathrm{~h}$ ) and (2) $3 \times / \mathrm{d}$ (at 0600, 1400, and $2200 \mathrm{~h}$ ). Cows were milked using a robotic milking system (Lely A3 Next, Lely Industries N.V., Maassluis, the Netherlands). At the specified milking times, cows were moved from the research pen into a small holding area adjacent to the robotic milker, from where they were milked individually and sequentially. Only the cows that were scheduled for milking, according to treatment, were moved into the holding area. Therefore, at $0600 \mathrm{~h}$, all 6 cows were moved into the holding area, and at each subsequent milking time (specific to each treatment), only 3 cows were moved into the holding area. Cows did not receive any supplemental feed from the robotic milking system while being milked. Each 21-d treatment period included $14 \mathrm{~d}$ for adaptation to each treatment followed by $7 \mathrm{~d}$ of data collection.

\section{Feeding Procedure}

Cows were individually assigned to one roughage intake feed bin (Insentec B.V., Marknesse, the Netherlands) to measure individual feed intake and feeding behavior, as validated by Chapinal et al. (2007). Cows received $3 \mathrm{~d}$ of training before the start of the experimental period to learn to access their own unique feed bin. Cows were fed a base TMR formulated to meet the nutrient requirements of a cow producing $39 \mathrm{~kg}$ of milk according to the NRC (2001) nutrient recommendations for high-producing lactating dairy cows. The TMR consisted of $30.4 \%$ grass/legume silage, $30.0 \%$ corn silage, $3.6 \%$ grass/alfalfa hay, $10.5 \%$ high moisture corn, $11.3 \%$ protein concentrate, and $14.3 \%$ robotic pellet supplement on a DM basis (Table 1). 
Table 1. Chemical composition (\% of DM unless otherwise noted) and particle size distribution of the experimental ration and components $($ mean $\pm \mathrm{SD})$

\begin{tabular}{|c|c|c|c|c|c|c|c|}
\hline Composition & $\begin{array}{l}\text { Corn } \\
\text { silage }\end{array}$ & $\begin{array}{c}\text { Grass/alfalfa } \\
\text { hay }\end{array}$ & $\begin{array}{l}\text { Grass/legume } \\
\text { silage }\end{array}$ & $\begin{array}{l}\text { High-moisture } \\
\text { corn }\end{array}$ & $\begin{array}{c}\text { Protein } \\
\text { concentrate }^{1}\end{array}$ & $\begin{array}{c}\text { Robotic } \\
\text { supplement }\end{array}$ & $\mathrm{TMR}^{3}$ \\
\hline \multicolumn{8}{|l|}{ Chemical composition ${ }^{4}$} \\
\hline $\mathrm{DM}(\%)$ & $41.7 \pm 1.5$ & $86.2 \pm 3.8$ & $37.8 \pm 3.4$ & $80.9 \pm 1.0$ & $92.1 \pm 0.4$ & $90.1 \pm 0.5$ & $48.9 \pm 1.0$ \\
\hline $\mathrm{CP}$ & $7.6 \pm 0.2$ & $13.7 \pm 1.3$ & $18.6 \pm 0.7$ & $9.1 \pm 0.1$ & $39.5 \pm 0.8$ & $19.7 \pm 0.5$ & $16.7 \pm 0.7$ \\
\hline $\mathrm{ADF}$ & $18.8 \pm 1.3$ & $45.1 \pm 2.1$ & $36.9 \pm 3.3$ & $4.5 \pm 0.7$ & $6.8 \pm 0.9$ & $6.8 \pm 0.6$ & $21.6 \pm 1.0$ \\
\hline NDF & $31.2 \pm 1.8$ & $56.2 \pm 3.0$ & $49.9 \pm 1.6$ & $11.1 \pm 0.4$ & $12.9 \pm 1.2$ & $26.5 \pm 1.4$ & $33.0 \pm 1.4$ \\
\hline Magnesium & $0.2 \pm 0.0$ & $0.2 \pm 0.0$ & $0.4 \pm 0.0$ & $0.2 \pm 0.0$ & $0.8 \pm 0.2$ & $0.4 \pm 0.0$ & $0.3 \pm 0.0$ \\
\hline Potassium & $0.6 \pm 0.1$ & $2.6 \pm 0.2$ & $3.0 \pm 0.5$ & $0.5 \pm 0.0$ & $1.7 \pm 0.1$ & $1.1 \pm 0.0$ & $1.7 \pm 0.2$ \\
\hline Sodium & $0.0 \pm 0.0$ & $0.0 \pm 0.0$ & $0.1 \pm 0.0$ & $0.0 \pm 0.0$ & $2.6 \pm 0.5$ & $0.3 \pm 0.0$ & $0.3 \pm 0.0$ \\
\hline Iron $(\mathrm{mg} / \mathrm{kg})$ & $50.5 \pm 3.4$ & $100.5 \pm 34.2$ & $731.3 \pm 51.5$ & $37.0 \pm 0.8$ & $784.8 \pm 237.0$ & $174.3 \pm 5.7$ & $466.2 \pm 185.4$ \\
\hline Manganese $(\mathrm{mg} / \mathrm{kg})$ & $13.8 \pm 2.2$ & $19.0 \pm 3.7$ & $55.0 \pm 6.2$ & $6.0 \pm 0.0$ & $336.8 \pm 102.7$ & $107.5 \pm 11.7$ & $82.3 \pm 7.2$ \\
\hline Zinc $(\mathrm{mg} / \mathrm{kg})$ & $22.3 \pm 1.7$ & $21.3 \pm 1.0$ & $29.5 \pm 1.9$ & $24.3 \pm 1.0$ & $407.5 \pm 78.4$ & $110.3 \pm 7.9$ & $80.6 \pm 9.1$ \\
\hline Copper $(\mathrm{mg} / \mathrm{kg})$ & $5.3 \pm 0.5$ & $11.0 \pm 0.8$ & $11.5 \pm 1.7$ & $1.0 \pm 0.0$ & $135.0 \pm 45.0$ & $23.3 \pm 0.50$ & $25.0 \pm 3.2$ \\
\hline \multicolumn{8}{|l|}{ Particle size $(\%)$} \\
\hline Long & $2.9 \pm 1.3$ & $76.3 \pm 12.9$ & $30.8 \pm 8.5$ & - & - & - & $16.7 \pm 6.6$ \\
\hline Medium & $62.8 \pm 4.1$ & $10.4 \pm 4.6$ & $44.2 \pm 5.8$ & - & - & - & $44.6 \pm 3.7$ \\
\hline Short & $32.4 \pm 4.8$ & $12.0 \pm 7.2$ & $21.4 \pm 4.3$ & - & - & - & $31.5 \pm 3.6$ \\
\hline Fine & $1.8 \pm 0.6$ & $4.3 \pm 3.0$ & $3.7 \pm 1.2$ & - & - & - & $7.1 \pm 2.0$ \\
\hline
\end{tabular}

${ }^{1}$ Supplied by Dundas Feed \& Seed Ltd. (Winchester, ON, Canada) and included the ingredients corn distillers, soybean meal, corn gluten meal, feather meal, blood meal, cane molasses, salt, calcium bicarbonate, dicalcium phosphate, magnesium oxide, sodium sesquicarbonte, magnesium potassium sulfate, animal fat, vitamins, and trace minerals.

${ }^{2}$ Supplied by Dundas Feed \& Seed Ltd. and included the ingredients ground wheat, wheat shorts, corn distillers, soybean meal, canola meal, cane molasses, salt, calcium bicarbonate, dicalcium phosphate, magnesium oxide, energy booster, vitamins, trace minerals, and flavor.

${ }^{3} \mathrm{NDF}$ composition (DM basis) of the long, medium, short, and fine particle fractions was $40.2 \pm 5.4 \%, 36.5 \pm 4.8 \%, 23.3 \pm 1.4 \%$, and $20.4 \pm$ $1.4 \%$, respectively.

${ }^{4}$ Values were obtained from chemical analysis of TMR and components. OM $=100-\%$ ash.

${ }^{5}$ Particle size determined by Penn State Particle Separator, which has a 19-mm screen (long), 8-mm screen (medium), 1.18-mm screen (short), and a pan (fine).

The TMR (without the robotic pellet supplement) was mixed once daily in a TMR mixer wagon (Jaylor 4425, Jaylor Fabricating, Orton, ON, Canada) and delivered via conveyor into a motorized feed cart (WIC RTM-55, WIC Inc., Wickham, QC, Canada) between 1000 and $1100 \mathrm{~h}$. The robotic pellet supplement was weighed on a scale (model 2020, Mettler-Toledo, Columbus, $\mathrm{OH}$ ) and mixed into the TMR for approximately 4 min, using the motorized feed cart.

Cows were denied access to the feed bins beginning at $1100 \mathrm{~h}$ daily, at which time feed refusals were removed and sampled as needed, and fresh feed was manually delivered into each feed bin. The total amount of feed offered was adjusted daily to ensure approximately $10 \%$ feed refusal per cow. Actual feed refusal averaged 10.5 $\pm 6.1 \%$ (mean $\pm \mathrm{SD}$ ) of the feed offered as fed over the course of the experiment and did not vary by treatment $(P=0.8)$. Cows were given access to the feed bins beginning at $1200 \mathrm{~h}$ daily; this time point served as the start of each data collection day.

\section{Behavioral Data Collection}

Feeding behavior was automatically monitored for each cow for the last $7 \mathrm{~d}$ of each experimental period using the Insentec system. From the recorded data, we were able to determine the duration of each visit to the feed bin, the amount of feed consumed (start weight end weight) during each visit, and the rate of consumption for each visit. These data were then summarized to calculate daily DMI $(\mathrm{kg} / \mathrm{d})$, daily time spent feeding $(\mathrm{min} / \mathrm{d})$, and average feeding rate $(\mathrm{kg} / \mathrm{min})$.

Lying behavior patterns of the cows were automatically collected using data loggers (Hobo Pendant G Logger, Onset Computer Corp., Pocasset, MA) for the last $7 \mathrm{~d}$ of each treatment period. These devices measured leg orientation at 1-min intervals and allowed all the standing and lying behavior data to be collected electronically (Ledgerwood et al., 2010). On d 14 of each period, data loggers were placed on the hind leg of each cow using veterinary bandaging tape (Vetrap Ban- 
daging Tape, 3M, London, ON, Canada) while the cow was restrained in a stall. Data loggers were removed from the cows on $\mathrm{d} 1$ of the following experimental period to ensure a complete 7 -d recording period. Data collected were used to calculate standing and lying duration (min/d), bout frequency (no./d), and bout length (min/bout). Duration of postmilking standing (min) was calculated as the difference in time between the end of milking and the first recorded instance when the cow lay down following milking.

For each milking, time away for milking was calculated as the difference in time from when the first cow to be milked entered the milking system to the time when each cow exited the milking system. From this, time away for milking per milking (min/milking) and time away for milking across the day $(\mathrm{min} / \mathrm{d})$ were calculated. Idle standing $(\mathrm{min} / \mathrm{d})$ was calculated as the difference in feeding time and time away for milking from the total standing time.

Rumination behavior was electronically monitored for the last $7 \mathrm{~d}$ of each treatment period using automatic rumination detection devices (Lely Qwes-HR collars, Lely Industries N.V.). The rumination logger, placed on the neck collar of the cow, continuously records the time spent ruminating within $24 \mathrm{~h}$ in $2-\mathrm{h}$ intervals, as validated by Schirmann et al. (2009). Data were transferred at each milking using an automatic reader located within the robotic milking system.

\section{Feed Sampling and Analysis}

For the last $7 \mathrm{~d}$ of each experimental period, duplicate samples of fresh feed were collected at feeding time for the determination of DM, nutrient content, and particle size distribution of the TMR. Duplicate samples of feed refusal for each cow were collected for determination of DM and for particle size separation to determine feed sorting. On d 1, 8, and 15 of each treatment period, duplicate samples of dietary components were collected for DM, chemical, and particle size analysis. All samples were immediately frozen at $-20^{\circ} \mathrm{C}$ until they were further analyzed.

Samples collected for particle size separation were separated using the 3 -screen (19, 8, $1.8 \mathrm{~mm})$ Penn State Particle Separator (PSPS; Kononoff et al., 2003). This separated the particles into 4 fractions: long $(>19 \mathrm{~mm})$, medium $(<19,>8 \mathrm{~mm})$, short $(<8,>1.18 \mathrm{~mm})$ and fine $(<1.18 \mathrm{~mm})$ particles. After separation, the DM of each separated fraction was determined by oven drying at $55^{\circ} \mathrm{C}$ for $48 \mathrm{~h}$. The particle fractions of the fresh TMR samples were ground to pass through a $1-\mathrm{mm}$ screen (Wiley mill, Arthur H. Thomas Co., Philadelphia, PA) and were analyzed for NDF using an Ankom ${ }^{2000}$ Fiber Analyzer (Ankom Technology, Macedon, NY) with heat-stable $\alpha$-amylase and sodium sulfite (Van Soest et al., 1991).

Samples collected for DM and chemical analysis were oven-dried at $55^{\circ} \mathrm{C}$ for $48 \mathrm{~h}$ and then ground to pass through a 1-mm screen (Wiley mill, Arthur H. Thomas Co.). These samples were sent to Cumberland Valley Analytical Services Inc. (Maugansville, MD) for analysis of DM $\left(135^{\circ} \mathrm{C}\right.$; AOAC International, 2000; method 930.15), ash $\left(535^{\circ} \mathrm{C}\right.$; AOAC International, 2000 ; method 942.05), ADF (AOAC International, 2000; method 973.18), NDF with heat-stable $\alpha$-amylase and sodium sulfite (Van Soest et al., 1991), and CP $(\mathrm{N} \times 6.25$; AOAC International, 2000; method 990.03; Leco FP528 Nitrogen Analyzer, Leco, St. Joseph, MI).

\section{Milk Production and Components}

Milk yield was automatically recorded at each milking for the last $7 \mathrm{~d}$ of each treatment period by the robotic milking system (Lely A3 Next, Lely Industries N.V.). Milk samples were collected from each milking for the last $3 \mathrm{~d}$ of each experimental period using the Lely Shuttle Sampling Device (Lely Industries N.V.). These samples were sent to the DHI testing laboratory (CanWest DHI, Guelph, ON, Canada) for analysis. Milk samples were analyzed for milk fat and protein percentage using a near-infrared analyzer (Foss System 4000 Infrared Transmission Analyzer, Foss, Hillerød, Denmark). For those days where milk components were measured, the yield of $4 \% \mathrm{FCM}(\mathrm{kg} / \mathrm{d})$ was calculated $(\mathrm{NRC}, 2001)$ as $0.4 \times$ milk yield $(\mathrm{kg} / \mathrm{d})+15.0 \times$ fat yield $(\mathrm{kg} / \mathrm{d})$. Energy-corrected milk was calculated using the following equation: $\mathrm{ECM}=(0.327 \times \mathrm{kg}$ of milk $)+(12.95 \times \mathrm{kg}$ of fat $)+(7.2 \times \mathrm{kg}$ of protein $)$ (Tyrrell and Reid, 1965). Efficiency of milk production was determined by calculating the kilograms of milk, $4 \%$ FCM yield, or ECM yield per kilogram of DMI for each treatment period.

\section{Calculations and Statistical Analysis}

Individual feeding bouts were separated into meals using an individual meal criterion for each cow on each treatment. Meal criteria were determined, as described by DeVries et al. (2003b), using a software package (MIX 3.1.3; MacDonald and Green, 1988) to fit a mixture of normal distributions to the distributions of $\log _{10}$-transformed time intervals between moments of feeding (across all $7 \mathrm{~d}$ of data recorded per treatment period). The average meal criterion was $40.7 \pm$ 27.7 min (mean $\pm \mathrm{SD}$ ) and did not vary by treatment $(P=0.6)$. The calculated meal criteria were used to calculate meal frequency (meals/d), by counting the number of intervals that exceeded the criterion and 
adding 1. Meal duration ( $\mathrm{min} / \mathrm{meal}$ ) was calculated as the time from the start of the first feeding bout until the end of the last feeding bout at which time the meal criterion was exceeded. Meal size $(\mathrm{kg} / \mathrm{meal})$ was calculated by dividing DMI by meal frequency. After an infinite number of iterations, we were unable to fit the individual intermeal distributions for $1 \mathrm{cow}$ on the $3 \times / \mathrm{d}$ treatment, resulting in no meal criterion for this animal for this period and exclusion of meal data from the statistical analysis.

Feed sorting was calculated as the actual DMI of each fraction of the PSPS expressed as a percentage of the predicted DMI of that fraction (Leonardi and Armentano, 2003). The actual intake of each individual fraction was calculated as the difference between the DM amount of each fraction in the offered feed and that in the refused feed. The predicted intake for each individual fraction was calculated as the product of the DMI of the total diet multiplied by the DM percentage of that fraction in the offered diet. Values equal to $100 \%$ indicate no sorting, values $<100 \%$ indicate selective refusals (sorting against), and values $>100 \%$ indicate preferential consumption (sorting for).

Before analyses, all data were screened for normality using the UNIVARIATE procedure of SAS (SAS Institute, 2009). Data collected for each day of each treatment data collection period, for each cow, were summarized for each cow by treatment period. To test whether feed sorting occurred, sorting activity for each fraction of the PSPS was summarized by treatment and tested for a difference from 100 using $t$-tests. All data were then analyzed using the MIXED procedure of SAS (SAS Institute, 2009). The final model included the fixed effects of parity (primiparous or multiparous; $\mathrm{df}=1,9)$, period $(1$ or $2 ; \mathrm{df}=1,9)$, order of treatment exposure $(1$ or 2 ; df $=1,9)$, treatment $(2 \times$ or $3 \times / \mathrm{d}$ milking; $\mathrm{df}=1,9)$, and parity $\times$ treatment interaction ( $\mathrm{df}=1,9)$. Other interactions of the fixed effects were tested in the initial model and were not significant; therefore, they were removed from the final model. The random effects were group and cow within order and group. Degrees of freedom for fixed effects were estimated using the Kenward-Roger option in the MODEL statement. When a parity $\times$ treatment interaction was detected the Tukey-Kramer method was used to adjust the probability differences between least squares means.

The regression procedure of SAS (SAS Institute, 2009) was used to examine the relationship between the amount of time cows spent away for milking (across the day and per milking) and the time devoted to other behaviors (feeding, lying, and ruminating). Only those statistically significant models are further reported.

Data for DMI, feeding time, feeding rate, and lying time were also summarized on an hourly basis, whereas ruminating time was summarized on a 2 -h basis, for each animal on each treatment. Differences between treatments in the distribution of these variables over a 24-h period were analyzed using the MIXED procedure of SAS, treating hour as a repeated measure. The final model included the fixed effects of parity (primiparous or multiparous; $\mathrm{df}=1,19)$, period ( 1 or 2 ; $\mathrm{df}=1,19$ ), order of treatment exposure ( 1 or 2 ; df $=1,19$ ), hour $(1-24 ; \mathrm{df}=23,506)$, treatment $(2 \times$ or $3 \times$ milking; $\mathrm{df}$ $=1,19)$, and hour $\times$ treatment interaction $(\mathrm{df}=23$, 506). Other interactions of the fixed effects were tested in the initial model and were not significant; therefore, they were removed from the final model. The random effects were group and cow within order and group. Cow within order and group was included in the model as the subject of the repeated statement. Compound symmetry was selected as the covariance structure on the basis of best fit according to Schwarz's Bayesian information criterion. Degrees of freedom were estimated using the Kenward-Roger option in the MODEL statement. All values reported are least squares means. Significance was declared at $P \leq 0.05$, and trends reported if $0.05<P \leq 0.10$.

\section{RESULTS}

Results for the effect of treatment on milk yield, composition, and efficiency are presented in Table 2. Average milk yield of cows milked $3 \times / \mathrm{d}$ increased by $2.9 \mathrm{~kg} / \mathrm{d}$ compared with cows milked $2 \times /$ d. Multiparous cows produced $8.2 \mathrm{~kg} / \mathrm{d}(25.5 \%)$ more milk over the course of the experiment than did primiparous cows. Primiparous cows and cows milked $3 \times / \mathrm{d}$ tended to have lower milk fat percentage than multiparous cows and cows milked $2 \times /$ d. Milk fat yield was lower for primiparous than for multiparous cows as a result of lower milk yield and fat percentage produced by primiparous cows. Treatment and parity had no effect on milk protein percentage. Cows milked $2 \times / \mathrm{d}$ had $0.1 \mathrm{~kg} / \mathrm{d}$ lower protein yield as a result of reduced milk yield. Primiparous cows produced $0.3 \mathrm{~kg} / \mathrm{d}$ less protein than multiparous cows. As a result, primiparous cows and cows milked $2 \times / \mathrm{d}$ had lower $4 \% \mathrm{FCM}$ and ECM than multiparous cows and cows milked $3 \times / d$, respectively. Cows milked $3 \times / d$ had greater milk production efficiency. There tended to be a treatment $\times$ parity interaction such that multiparous cows had greater ECM efficiency when milked $3 \times / d$ compared with when milked $2 \times / d$. We observed no further interactions between parity and treatment for any other milk yield, composition, or efficiency variables.

Primiparous cows consumed $3.8 \mathrm{~kg} / \mathrm{d}(15.7 \%)$ less DM than multiparous cows; there tended to be a treatment $\times$ parity interaction such that primiparous milked $3 \times / d$ tended to have greater DMI compared 
Table 2. Effect of milking frequency (F; $2 \times$ or $3 \times$ daily) and parity (P; primiparous, Primi, or multiparous, Multi) on milk yield, milk composition, milk component yield, and efficiency of production

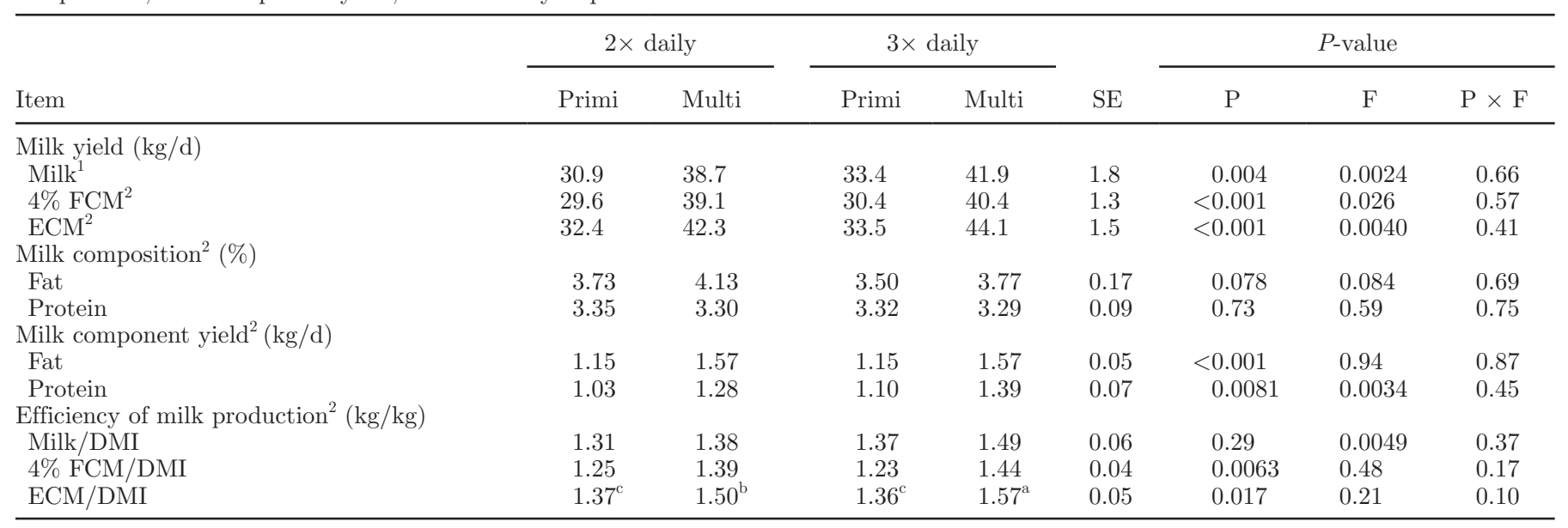

${ }^{\mathrm{a}-\mathrm{c}}$ Means within a row with different superscripts differ $(P \leq 0.05$; adjusted for multiple comparisons using the Tukey-Kramer procedure).

${ }^{1}$ Data averaged over $7 \mathrm{~d}$ for 12 cows on each treatment.

${ }^{2}$ Data averaged over $3 \mathrm{~d}$ for 12 cows on each treatment.

with primiparous cows milked $2 \times /$ d (Table 3$)$. We also observed a tendency for cows milked $2 \times / \mathrm{d}$ to spend less time feeding and, thus, consume their feed at a faster rate than cows milked $3 \times /$ d. However, parity or treatment $\times$ parity interaction had no effect of on total feeding time $(\mathrm{min} / \mathrm{d})$.

The analysis of diurnal feeding activity indicated differences in the distribution of feeding activity throughout the day, as observed by a treatment $x$ hour interaction for DMI $(P=0.008$; Figure 1$)$, feeding time $(P=$ 0.009 ; Figure 2$)$, and feeding rate $(P=0.04$; Figure 3$)$. Between $2100 \mathrm{~h}$ and $1200 \mathrm{~h}$ the following day, all cows, regardless of treatment, demonstrated very similar patterns in DMI and feeding time. Cows milked $3 \times / \mathrm{d}$ showed a secondary peak in feeding activity following the $1400 \mathrm{~h}$ milking, whereas feeding activity of cows milked $2 \times / \mathrm{d}$ decreased more steadily following fresh feed delivery at $1200 \mathrm{~h}$. At the time of the $1800 \mathrm{~h}$ and $2200 \mathrm{~h}$ milkings, all cows showed an increase in feeding activity. However, DMI and feeding rate of cows that were not milked, particularly around the $1800 \mathrm{~h}$ milking, were lower than those that were milked. Curiously, cows milked $3 \times / \mathrm{d}$ showed an additional peak in feeding activity around $2000 \mathrm{~h}$.

Alterations in feeding activity in response to milking frequency are likely related to a change in meal patterns (Table 3). A treatment $\times$ parity interaction for meal frequency indicated that primiparous cows were most affected by increased milking frequency, resulting in them consuming 1.4 more meals/d when milked $3 \times / d$.

Table 3. Effect of milking frequency (F; $2 \times$ or $3 \times$ daily) and parity (P; primiparous, Primi, or multiparous, Multi) on DMI, feeding behavior, rumination time, lying behavior, postmilking standing time, and time away for milking ${ }^{1}$

\begin{tabular}{|c|c|c|c|c|c|c|c|c|}
\hline \multirow[b]{2}{*}{ Item } & \multicolumn{2}{|c|}{$2 \times$ daily } & \multicolumn{2}{|c|}{$3 \times$ daily } & \multirow[b]{2}{*}{$\mathrm{SE}$} & \multicolumn{3}{|c|}{$P$-value } \\
\hline & Primi & Multi & Primi & Multi & & $\mathrm{P}$ & $\mathrm{F}$ & $\mathrm{P} \times \mathrm{F}$ \\
\hline DMI $(\mathrm{kg} / \mathrm{d})$ & $23.6^{\mathrm{c}}$ & $28.2^{\mathrm{a}}$ & $24.7^{\mathrm{b}}$ & $28.0^{\mathrm{a}}$ & 0.6 & $<0.001$ & 0.22 & 0.084 \\
\hline Feeding time $(\min / \mathrm{d})$ & 221.6 & 227.6 & 227.1 & 248.0 & 21.9 & 0.54 & 0.10 & 0.34 \\
\hline Feeding rate $(\mathrm{kg} / \mathrm{min})$ & 0.12 & 0.14 & 0.12 & 0.13 & 0.02 & 0.35 & 0.069 & 0.16 \\
\hline Meal frequency (meals/d) & $7.7^{\mathrm{b}}$ & $6.7^{\mathrm{b}}$ & $9.1^{\mathrm{a}}$ & $6.7^{\mathrm{b}}$ & 1.2 & 0.15 & 0.039 & 0.044 \\
\hline Meal size $(\mathrm{kg} / \mathrm{meal})$ & $3.2^{\mathrm{b}}$ & $4.6^{\mathrm{a}}$ & $2.9^{c}$ & $4.8^{\mathrm{a}}$ & 0.7 & 0.033 & 0.37 & 0.051 \\
\hline Meal duration (min/meal) & $29.3^{\mathrm{c}}$ & $36.8^{\mathrm{b}}$ & $25.8^{\mathrm{d}}$ & $40.1^{\mathrm{a}}$ & 3.3 & 0.019 & 0.94 & 0.0041 \\
\hline Rumination time (min/d) & 473.5 & 529.1 & 468.5 & 553.2 & 37.1 & 0.18 & 0.21 & 0.073 \\
\hline Lying bouts (no./d) & 10.3 & 10.6 & 10.0 & 9.1 & 1.8 & 0.83 & 0.18 & 0.38 \\
\hline Lying time $(\mathrm{min} / \mathrm{d})$ & 702.7 & 705.7 & 681.6 & 688.7 & 80.4 & 0.96 & 0.56 & 0.95 \\
\hline Idle standing ${ }^{2}(\mathrm{~min} / \mathrm{d})$ & 473.0 & 457.3 & 475.7 & 432.5 & 66.7 & 0.72 & 0.78 & 0.72 \\
\hline Postmilking standing (min) & 59.8 & 83.1 & 65.6 & 67.8 & 12.0 & 0.33 & 0.64 & 0.32 \\
\hline Time away for milking (min/d) & 47.4 & 44.3 & 62.9 & 58.1 & 9.6 & 0.75 & $<0.001$ & 0.78 \\
\hline Time away for milking (min/milking) & 23.7 & 22.2 & 21.0 & 19.4 & 3.8 & 0.76 & 0.034 & 0.97 \\
\hline
\end{tabular}

${ }^{\mathrm{a}-\mathrm{d}}$ Means within a row with different superscripts differ $(P \leq 0.05$; adjusted for multiple comparisons using the Tukey-Kramer procedure).

${ }^{1}$ Data averaged over $7 \mathrm{~d}$ for 12 cows on each treatment.

${ }^{2}$ Idle standing $(\min / \mathrm{d})=$ standing time $(\min / \mathrm{d})$ - feeding time $(\min / \mathrm{d})$ - time away for milking $(\mathrm{min} / \mathrm{d})$. 


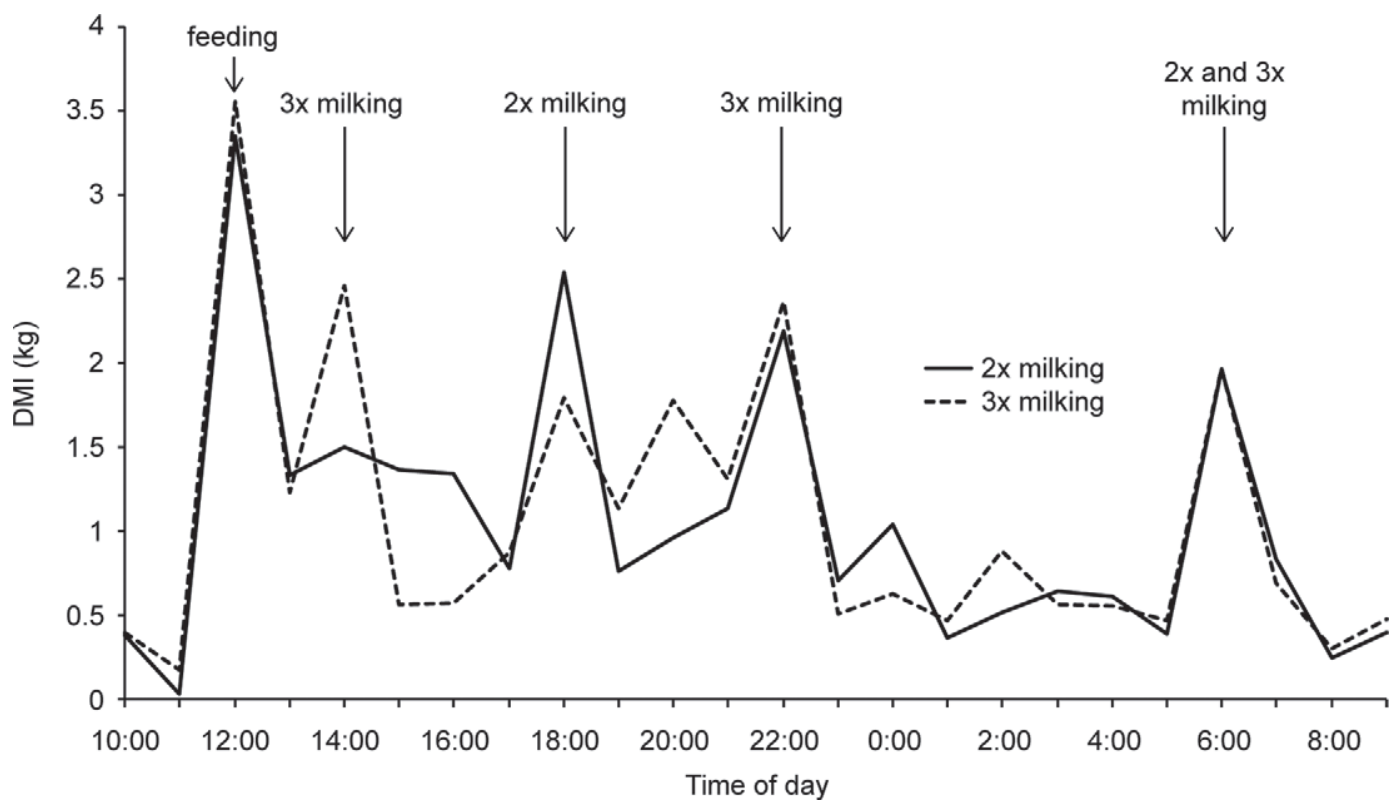

Figure 1. Hourly average DMI (kg) of lactating dairy cows milked (1) $2 \times / \mathrm{d}$ or (2) $3 \times / \mathrm{d}$. Data are averaged over 7 d for 12 cows on each treatment.

A treatment $\times$ parity interaction was also observed for meal size and meal duration; primiparous cows milked $3 \times / d$ consumed more frequent, shorter, and smaller meals throughout the day.

Cows milked $3 \times / \mathrm{d}$ spent $14.6 \mathrm{~min} / \mathrm{d}$ more time away from their home pen for milking compared with cows milked $2 \times / \mathrm{d}$ (Table 3 ). However, cows milked $3 \times / \mathrm{d}$ spent $2.8 \mathrm{~min} /$ milking less time away from their home pen. Across treatments, daily lying time was negatively associated with total time spent away for milking [lying time $(\mathrm{min} / \mathrm{d})=-3.6 \times$ total time away for milking $\left.(\min / \mathrm{d})+873.8 ; \mathrm{R}^{2}=0.30 ; P=0.007\right]$ and average

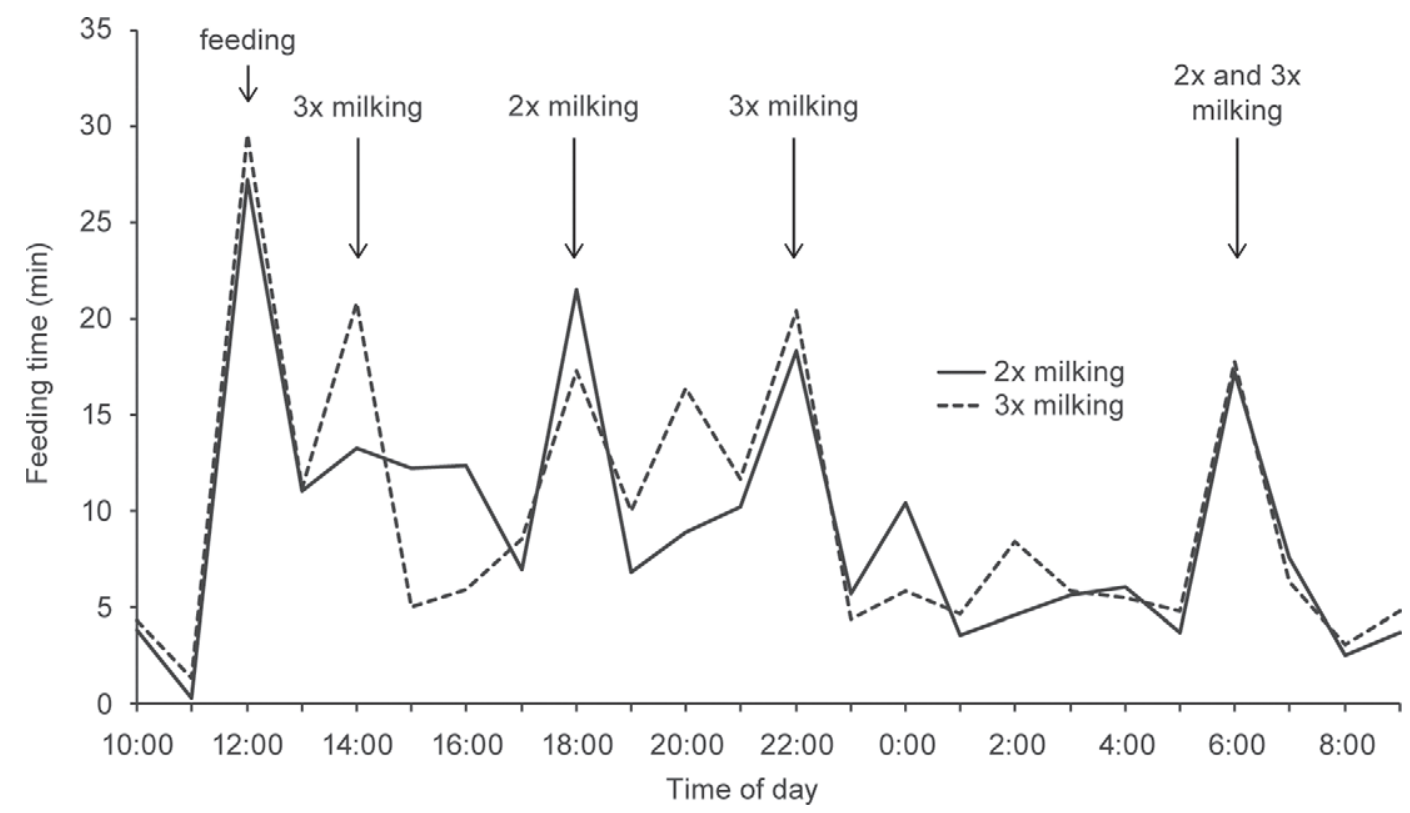

Figure 2. Hourly average feeding time (min) of lactating dairy cows milked (1) $2 \times / \mathrm{d}$ or (2) $3 \times /$ d. Data are averaged over 7 d for 12 cows on each treatment. 


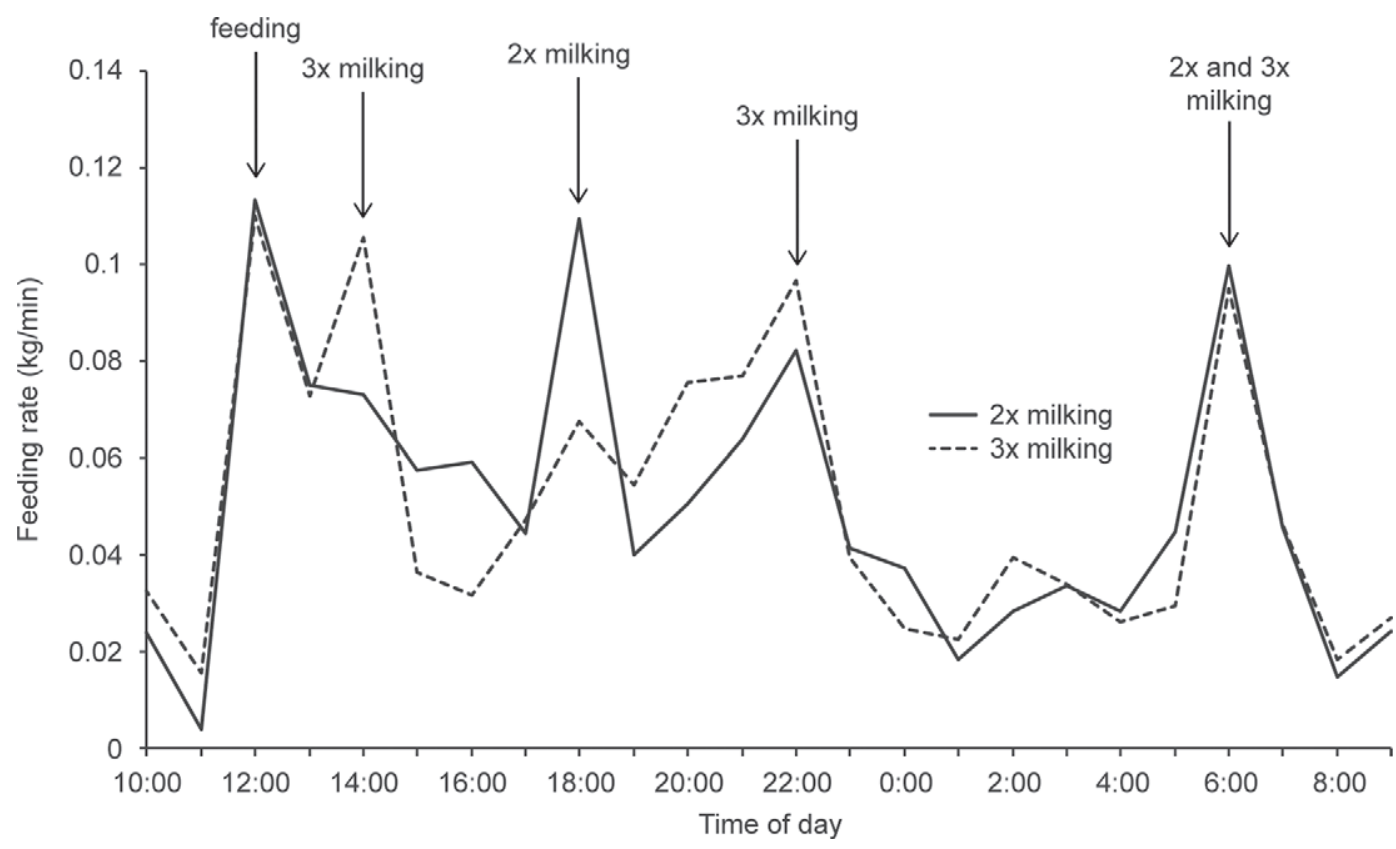

Figure 3. Hourly average feeding rate $(\mathrm{kg} / \mathrm{min})$ of lactating dairy cows milked (1) $2 \times / \mathrm{d}$ or (2) $3 \times / \mathrm{d}$. Data are averaged over $7 \mathrm{~d}$ for 12 cows on each treatment.

time away for each milking [lying time $(\mathrm{min} / \mathrm{d})=-8.6$ $\times$ average time away for milking ( $\mathrm{min} /$ milking) + $\left.870.4 ; \mathrm{R}^{2}=0.25 ; P=0.016\right]$.

We observed no effect of treatment or parity on total lying time, lying bouts, amount of time spent standing idle, or postmilking standing time of the cows (Table 3 ). However, analysis of diurnal lying activity indicated differences in the distribution of lying activity throughout the day, as observed by a treatment $\times$ hour interaction for lying time $(P<0.001$; Figure 4). Between 0100 and $1100 \mathrm{~h}$, all cows, regardless of treatment, demonstrated very similar patterns in lying behavior, indicating that the greatest periods of lying activity occurred before and after the $0600 \mathrm{~h}$ milking. However, during the afternoon and evening period (1200 to $2300 \mathrm{~h}$ ), lying time differed between treatments. Cows milked $2 \times / \mathrm{d}$ exhibited 2 smaller peaks in lying activity occurring around the $1800 \mathrm{~h}$ milking, whereas cows milked $3 \times / \mathrm{d}$ exhibited one larger peak in lying activity during the afternoon and evening period.

Treatment and parity did not affect total rumination time (Table 3). We observed a tendency for a treatment $\times$ parity interaction for rumination time; however, no differences among means were detected. No treatment $x$ hour interaction was found for rumination activity $(P=0.6$; Figure 5$)$.

We observed no sorting for or against long particles $(>19.0 \mathrm{~mm})$ or fine particles $(<1.18 \mathrm{~mm})$ (Table 4$)$. Across treatments, we did observe sorting for medium particles. A tendency was found for a treatment $\times$ par- ity interaction for sorting for medium particles; however, no differences among means were detected. Multiparous cows tended to sort against short particles $(<8.0,>1.18$ $\mathrm{mm}$ ) on both treatments, whereas primiparous cows showed no significant sorting of this fraction.

\section{DISCUSSION}

Many dairy producers milk on a $3 \times / d$ schedule to maximize parlor efficiency and productivity. Previous research in this area has focused on the effect of milking frequency on milk production and lactation persistency. Although the results of this study are consistent with the literature in terms of expected production responses, this is the first study to demonstrate how milking $3 \times$ compared with $2 \times /$ d affects behavioral patterns and how this response differs between multiparous and primiparous cows.

Cows milked $3 \times / \mathrm{d}$ increased their average milk yield by $2.9 \mathrm{~kg} / \mathrm{d}$ compared with cows milked $2 \times / \mathrm{d}$, which is consistent with the results from a review of previous literature (Erdman and Varner, 1995). However, the magnitude of milk yield response in the current study $(8.3 \%)$ was lower than the previously reported increases in milk yield of 10.4 to $19.9 \%$ (Amos et al., 1985; Gisi et al., 1986; Klei et al., 1997; Smith et al., 2002). It is possible that the stage of lactation of the cows used in this study (149.5 \pm 31.3 DIM at the onset) affected their sensitivity to treatment, resulting in a lesser milk yield response. Klei et al. (1997) demonstrated that, relative 


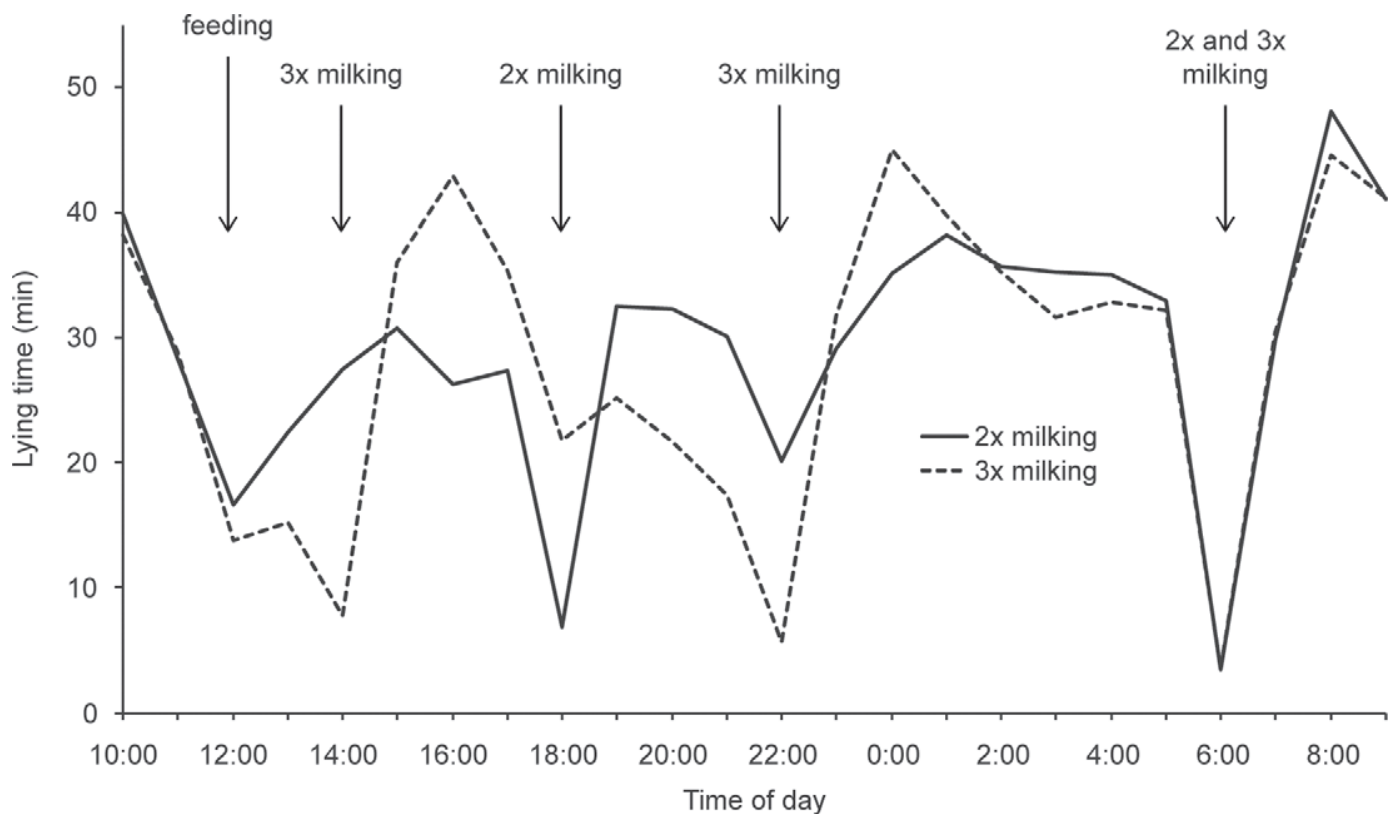

Figure 4. Hourly average lying time (min) of lactating dairy cows milked (1) $2 \times / \mathrm{d}$ or (2) $3 \times / \mathrm{d}$. Data are averaged over $7 \mathrm{~d}$ for 12 cows on each treatment.

to $2 \times /$ d milking, cows milked $3 \times /$ d from parturition increased milk yield by $10.4 \%$ compared with 7.8 and $0.06 \%$ increases in cows switched to $3 \times / \mathrm{d}$ milking at 100 and 200 DIM, respectively. Thus, as cows get further into lactation, the magnitude of milk yield response is diminished when milking frequency increases.

In the current study, cows milked $3 \times / \mathrm{d}$ tended to produce milk that was 0.3 percentage points lower in milk fat than cows milked $2 \times / \mathrm{d}$, which is consistent with previous research (Klei et al., 1997; Smith et al., 2002). However, despite the greater milk yield for cows milked $3 \times / \mathrm{d}$, treatment did not affect milk fat yield, which disagrees with Klei et al. (1997), who found that cows milked $3 \times / \mathrm{d}$ yield $4.7 \%$ more milk fat. In contrast to results reported by Klei et al. (1997) and Smith et al. (2002), milking frequency did not affect milk protein

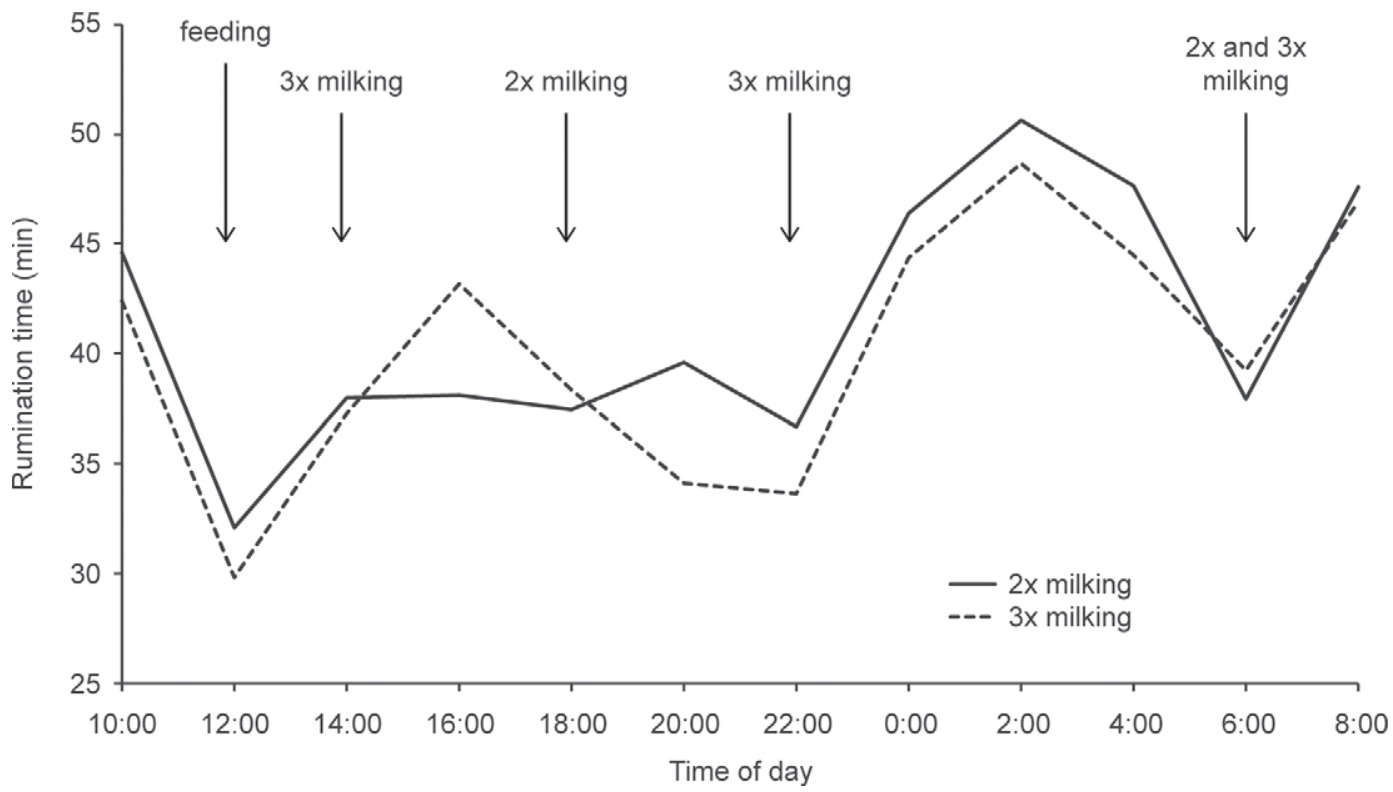

Figure 5. Bihourly average rumination time (min) of lactating dairy cows milked (1) $2 \times / \mathrm{d}$ or (2) $3 \times /$ d. Data are averaged over $7 \mathrm{~d}$ for 12 cows on each treatment. 
Table 4. Effect of milking frequency (F; $2 \times$ or $3 \times$ daily) and parity (P; primiparous, Primi, or multiparous, Multi) on the sorting (\%) of long, medium, short, and fine particles

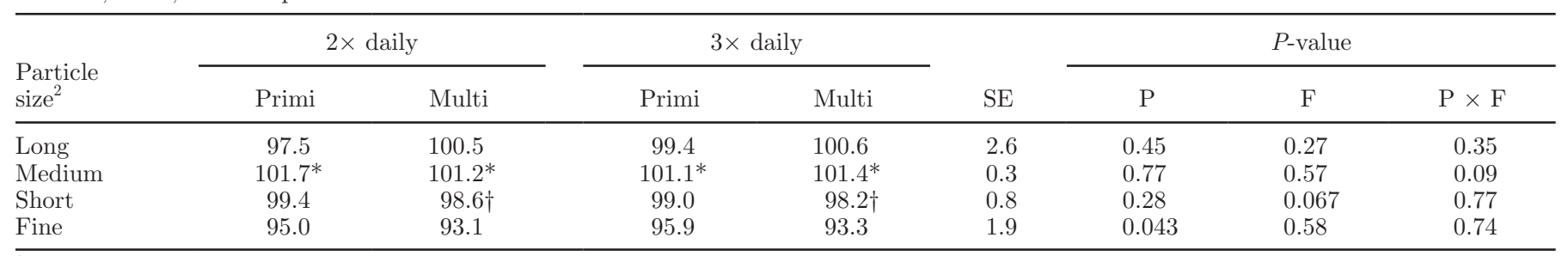

${ }^{1}$ Sorting $\%=100 \times($ particle size $\mathrm{n}$ DM intake/particle size $\mathrm{n}$ predicted DM intake), where $\mathrm{n}=$ long, medium, short, or fine particle fraction. Sorting values equal to $100 \%$ indicate no sorting, $<100 \%$ indicate selective refusals (sorting against), and $>100 \%$ indicate preferential consumption (sorting for). Data are averaged over $7 \mathrm{~d}$ for 12 cows on each treatment.

${ }^{2}$ Particle size determined by a Penn State Particle Separator, which has a 19-mm screen (long), 8-mm screen (medium), 1.18-mm screen (short), and a pan (fine).

$* P<0.05, \dagger P<0.10$ : difference in sorting values from $100 \%$.

percentage in the current study. Cows milked $3 \times / \mathrm{d}$ in the present study did have a $7.8 \%$ greater milk protein yield, which is consistent with the findings of Klei et al. (1997). Thus, even though the response of milk composition and milk component yield to milking frequency is typically consistent (Erdman and Varner, 1995), variation exists across studies in these responses. This variation may be attributed to differences in methodology (e.g., cow genetics, diet composition, experimental procedures). Despite the less consistent response in milk composition and milk component yield in the current study, when accounting for milk composition, milking $3 \times / \mathrm{d}$ did improve both FCM and ECM yields; this is consistent with previous research (Barnes et al., 1990; Smith et al., 2002).

Multiparous cows had $25.5 \%$ greater milk yield, $36.7 \%$ greater fat yield, and $25.5 \%$ greater protein yield and, therefore, greater FCM and ECM than primiparous cows. Greater milk component yield of multiparous cows is consistent with previous research (Klei et al., 1997). The response to milking frequency was similar for both primiparous and multiparous cows in the present study. Although some research has indicated that primiparous cows have greater milk yield when milked $3 \times /$ d (Gisi et al., 1986; Barnes et al., 1990), this is not a consistent response, as demonstrated by Erdman and Varner (1995) and the current study. Further research is required to understand the conditions that cause primiparous cows to be more influenced by milking frequency than multiparous cows.

Despite the production benefits of increased milking frequency, the time required for extra milking could reduce the time available for feeding, rumination, and lying behaviors. For this reason, there is interest in understanding the effect that milking frequency has on the behavioral patterns of lactating dairy cows. Contrary to the hypothesis above, cows tended to spend more time feeding, at a slower rate, when milked $3 \times / d$.
This increase in feeding activity was notable around the times when cows were milked (Figures 2 and 3 ) and provides further evidence that cows are motivated to feed around the time of milking (DeVries et al., 2003a), albeit not with the same level of motivation as seen at the time of feed delivery (Figures 1 and 2; DeVries and von Keyserlingk, 2005). For multiparous cows, the increase in feeding activity was facilitated through having longer, and slightly larger meals when milked $3 \times /$ d. In contrast, primiparous cows consumed smaller, more frequent meals throughout the day when milked $3 \times / d$. For the primiparous cows, this translated into a tendency for them to have greater DMI when milked $3 \times /$ d. The lack of effect of milking frequency on DMI of multiparous cows is not surprising, as this effect is common across studies (Amos et al., 1985; DePeters et al., 1985; Barnes et al., 1990; Patton et al., 2006). It has been concluded that cows milked $3 \times / \mathrm{d}$ utilize feed nutrients and experience a greater rate of tissue catabolism to achieve greater production efficiency (Amos et al., 1985), which is in agreement with the multiparous cows in the present study. Lower-producing cows, such as primiparous cows, typically do not convert feed to milk as efficiently as higher-producing cows (DePeters et al., 1985); this was also confirmed by the present study. Thus, to achieve the same increase in milk yield at greater milking frequency, as in the current study, the primiparous cows had to consume more DM, in a manner more conducive to stable and efficient rumen fermentation (Shabi et al., 1999).

As seen in Figure 5, periods when cows spend more time ruminating are associated with lower feeding activity (Figure 2) and, thus, lower DMI (Figure 1), as cows are unable to consume feed and ruminate simultaneously (Schirmann et al., 2012). In the present study, 3 large peaks in rumination activity were observed throughout the day, coinciding with the periods of lowest feeding activity. Norring et al. (2012) observed that 
as a cow's milk yield increases, lying time decreases and time spent ruminating while standing increases; this is likely due to increased time spent feeding to meet increased metabolic demands required to support that yield. In the current study, however, the increase in feeding time associated with milking more frequently was not substantial enough to elicit any reduction in rumination time or lying time. In the current study, we were unable to calculate whether rumination was occurring while standing or lying. However, we speculate that there may be a difference in the amount of time spent ruminating while standing and ruminating while lying because of differences in the distribution of lying time in the afternoon and evening periods (Figure 4). Furthermore, we suspect that as the amount of time spent milking increases, a proportional increase in the amount of time spent ruminating while standing might occur, but further research is required quantify this effect.

Although we observed no significant effect of milking frequency on total lying time in the present study, which agrees with the results of Tucker et al. (2007) for cows milked $1 \times / \mathrm{d}$ and $2 \times / \mathrm{d}$, the distribution of lying time was affected by when cows were milked, as would be expected. These results provide further evidence that cows have a strong motivation for lying (Metz, 1985). In previous research, lying has been demonstrated to be a greater priority over feeding after cows have been simultaneously deprived of the opportunity to do both (Metz, 1985; Munksgaard et al., 2005). Thus, management practices such as greater milking frequency, which may result in cows spending more time standing (waiting to be milked and feeding at the feed bunk), do not necessarily always have a negative effect on lying time.

A reduction in lying time was expected in the current study for cows milked $3 \times / d$, not only because of possible trade-offs with feeding time, but also because the time required for an extra milking would increase the time cows spend away from their home pen. In the current study, cows milked $3 \times /$ d spent approximately 15 $\mathrm{min} / \mathrm{d}$ more time away from their home pen for milking per day. Correspondingly, cows milked $3 \times / \mathrm{d}$ spent approximately $19 \mathrm{~min} / \mathrm{d}$ less time lying down, but this was a numerical (nonsignificant) difference in lying time. It is interesting to note that, across treatments, lying time was negatively associated with total time spent away for milking. This suggests that in situations where time away for milking is greater (e.g., milking large groups of cows $3 \times / d$ ), the risk for a reduction in lying time for certain cows may be greater.

It has been observed that increased time spent milking is associated with a decrease in other behaviors, such as feeding and lying (Gomez and Cook, 2010). Therefore, it was also hypothesized that the extra time required for milking $3 \times / \mathrm{d}$ may cause cows to lie down sooner after milking. Lying down immediately after milking has been related to greater herd SCC (Barnouin et al., 2004), as well as greater incidence of subclinical (DeVries et al., 2010) and clinical (Peeler et al., 2000) mastitis. In the present study, milking frequency had no effect on postmilking standing time. The average postmilking standing time (68 $\pm 24 \mathrm{~min}$; mean $\pm \mathrm{SD}$ ) is consistent with reports from other studies involving freestall-housed cows (35 min: Tyler et al., 1997; 55 min: DeVries and von Keyserlingk, 2005; 62 min: DeVries et al., 2005; 33 min: Fregonesi et al., 2007). The lack of treatment effect may be a result of the size of the group of cows tested in each replicate and the facility design. At the $0600 \mathrm{~h}$ milking, all 6 cows were milked; therefore, the last cow to be milked would have stood in the holding area for up to $1 \mathrm{~h}$. At all subsequent milkings, when only 3 cows were milked, the last cow to be milked was only in the holding area for a maximum of 20 to $30 \mathrm{~min}$. These times may not be fully representative of a commercial situation, where cows milked $3 \times / \mathrm{d}$ spend, on average, 1.2 to $5.7 \mathrm{~h} / \mathrm{d}$ out of their home pen (Gomez and Cook, 2010). It is possible that, as cows spend longer periods of time standing in holding areas, they may be more motivated to lie sooner after milking. This is speculative, thus further research is required to determine how much time cows need to be deprived from feeding and lying (i.e., time spent in the holding area) to cause a change in their postmilking standing time.

When one animal eats, another may be stimulated to do likewise, whether it is hungry or not, which is known as social facilitation (Curtis and Houpt, 1983). Around the time of the 1800 and $2200 \mathrm{~h}$ milkings, all cows showed an increase in feeding activity, regardless of treatment, indicating that social facilitation influenced feeding patterns at these times. Dairy cattle are motivated to feed following the return from milking (DeVries et al., 2003a); therefore, the act of cows on one treatment returning from milking could have motivated the other cows to seek feed as well. This is obviously a limitation of the experimental setup. However, conducting this experiment in identical, isolated facilities would introduce greater sources of error (i.e., confounding location with treatment). The benefit of the present design was that cows on both treatments were subject to identical environmental conditions; thus, we are confident that any differences observed overcame any social facilitation and can be directly attributed to the treatments imposed. However, we caution the interpretation and application of these results at the farm level, because it is highly unlikely for parlor-milked cows housed in the same pen to be milked at different frequencies. Further research is thus needed to determine if the observed ef- 
fect of milking $3 \times / \mathrm{d}$ on behavioral time budgets holds under commercial settings.

\section{CONCLUSIONS}

Cows milked $3 \times / \mathrm{d}$ and multiparous cows produced more milk than those milked $2 \times / \mathrm{d}$ and primiparous cows, respectively. The extra time required for milking $3 \times / d$ altered the distribution of cow behavioral activity throughout the day. Although this did not affect total daily lying or rumination time, feeding time did tend to increase. For multiparous cows, the increase in feeding activity was facilitated through having longer and slightly larger meals when milked $3 \times /$ d. Alternatively, primiparous cows consumed smaller, more frequent meals throughout the day when milked $3 \times / d$, resulting in a tendency for greater DMI. These results indicate that under $3 \times / \mathrm{d}$ milking schedules, primiparous cows will positively adjust their feeding behavior to achieve similar production increases as multiparous cows. Overall, milking $3 \times / \mathrm{d}$ can be used to increase production; however, greater milking frequency elicits varying effects on the behavior of primiparous and multiparous cows, suggesting that grouping and management of cows based on parity may be beneficial.

\section{ACKNOWLEDGMENTS}

We thank the staff and students at the University of Guelph, Kemptville Campus Dairy Education and Innovation Centre (Kemptville, ON, Canada). In particular, we thank Albert Koekkoek, Megan Bruce, Alex Watters, and Ryan Garner of the University of Guelph, Kemptville Campus, for their technical help. This project was financially supported by a Natural Sciences and Engineering Research Council of Canada (NSERC; Ottawa, ON, Canada) Collaborative Research and Development Grant with the Dairy Farmers of Ontario (Mississauga, ON, Canada) and an Ontario Ministry of Agriculture, Food and Rural Affairs (OMAFRA; Guelph, ON, Canada)/University of Guelph Production Systems research grant. Additional project support was received from the Canadian Foundation for Innovation (CFI; Ottawa, ON, Canada) and the Ontario Research Fund (Toronto, ON, Canada).

\section{REFERENCES}

Amos, H. E., T. Kiser, and M. Loewenstein. 1985. Influence of milking frequency on productive and reproductive efficiencies of dairy cows. J. Dairy Sci. 68:732-739.

AOAC International. 2000. Official Methods of Analysis. Vol. I. 17th ed. AOAC International, Arlington, VA.

Bar-Peled, U., E. Maltz, I. Bruckental, Y. Folman, Y. Kali, H. Gacitua, and A. R. Lehrer. 1995. Relationship between frequent milking or suckling in early lactation and milk production of high producing dairy cows. J. Dairy Sci. 78:2726-2736.

Barnes, M. A., R. E. Pearson, and A. J. Lukes-Wilson. 1990. Effects of milking frequency and selection for milk yield on productive efficiency of Holstein cows. J. Dairy Sci. 73:1603-1611.

Barnouin, J., M. Chassagne, S. Bazin, and D. Boichard. 2004. Management practices from questionnaire surveys in herds with very low somatic cell score through a national mastitis program in France. J. Dairy Sci. 87:3989-3999.

Cabrera, V. E., D. Solis, and J. del Corral. 2010. Determinants of technical efficiency among dairy farms in Wisconsin. J. Dairy Sci. 93:387-393.

CCAC (Canadian Council on Animal Care). 2009. Guidelines on: The care and use of farm animals in research, teaching and testing. Canadian Council on Animal Care, Ottawa, ON, Canada.

Chapinal, N., D. M. Veira, D. M. Weary, and M. A. G. von Keyserlingk. 2007. Technical note: Validation of a system for monitoring individual feeding and drinking behavior and intake in group housed dairy cows. J. Dairy Sci. 990:5732-5736.

Curtis, S. E., and K. A. Houpt. 1983. Animal ethology: Its emergence in animal science. J. Anim. Sci. 57:234-247.

Dahl, G. E., R. L. Wallace, R. D. Shanks, and D. Lueking. 2004. Hot topic: Effects of frequent milking in early lactation on milk yield and udder health. J. Dairy Sci. 87:882-885.

DePeters, E. J., N. E. Smith, and J. Acedo-Rico. 1985. Three and two times daily milking of older cows and first lactation cows for entire lactations. J. Dairy Sci. 68:123-132.

DeVries, T. J., S. Dufour, and D. T. Scholl. 2010. Relationship between feeding strategy, lying behavior patterns, and incidence of intramammary infection in dairy cows. J. Dairy Sci. 93:1987-1997.

DeVries, T. J., and M. A. G. von Keyserlingk. 2005. Time of feed delivery affects the feeding and lying patterns of dairy cows. J. Dairy Sci. 88:625-631.

DeVries, T. J., M. A. G. von Keyserlingk, and K. A. Beauchemin 2003a. Diurnal feeding pattern of lactating dairy cows. J. Dairy Sci. 86:4079-4082.

DeVries, T. J., M. A. G. von Keyserlingk, and K. A. Beauchemin. 2005. Frequency of feed delivery affects the behavior of lactating dairy cows. J. Dairy Sci. 88:3553-3562.

DeVries, T. J., M. A. G. von Keyserlingk, D. M. Weary, and K. A Beauchemin. 2003b. Measuring the feeding behavior of lactating dairy cows in early to peak lactation. J. Dairy Sci. 86:3354-3361.

Erdman, R. A., and M. Varner. 1995. Fixed yield responses to increased milking frequency. J. Dairy Sci. 78:1199-1203.

Fregonesi, J. A., C. B. Tucker, and D. M. Weary. 2007. Overstocking reduces lying time in dairy cows. J. Dairy Sci. 90:3349-3354.

Gisi, D. D., E. J. DePeters, and C. L. Pelsissier. 1986. Three times daily milking of cows in California dairy herds. J. Dairy Sci. 69:863-868.

Gomez, A., and N. B. Cook. 2010. Time budgets of lactating dairy cattle in commercial freestall herds. J. Dairy Sci. 93:5772-5781.

Hale, S. A., A. V. Capuco, and R. A. Erdman. 2003. Milk yield and mammary growth effects due to increased milking frequency during early lactation. J. Dairy Sci. 86:2061-2071.

Klei, L. R., J. M. Lynch, D. M. Barbano, P. A. Oltenacu, A. J. Lednor, and D. K. Bandler. 1997. Influence of milking three times a day on milk quality. J. Dairy Sci. 80:427-436.

Kononoff, P. J., A. J. Heinrichs, and D. R. Buckmaster. 2003. Modification of Penn State forage and total mixed ration particle separator and the effects of moisture content on its measurement. J. Dairy Sci. 86:1858-1863.

Ledgerwood, D. N., C. Winckler, and C. B. Tucker. 2010. Evaluation of data loggers, sampling intervals, and editing techniques for measuring the lying behavior of dairy cattle. J. Dairy Sci. 93:5129-5139

Leonardi, C., and L. E. Armentano. 2003. Effect of quantity, quality, and length of alfalfa hay on selective consumption by dairy cows. J. Dairy Sci. 86:557-564.

MacDonald, P. D. M., and P. E. J. Green. 1988. User's Guide to Program MIX: An interactive program for fitting mixtures of distribu- 
tions. Release 2.3, January 1988. Ichthus Data Systems, Hamilton, ON, Canada.

Metz, J. H. M. 1985. The reaction of cows to a short-term deprivation of lying. Appl. Anim. Behav. Sci. 13:301-307.

Morris, T. R. 1999. Experimental Design and Analysis in Animal Sciences. CABI Publishing, New York, NY.

Munksgaard, L., M. G. Jensen, L. J. Pedersen, S. W. Hansen, and L. Matthews. 2005. Quantifying behavioural priorities - Effects of time constraints on behavior of dairy cows, Bos taurus. Appl. Anim. Behav. Sci. 92:3-14.

Norring, M., A. Valros, and L. Munksgaard. 2012. Milk yield affects time budget of dairy cows in tie-stalls. J. Dairy Sci. 95:102-108.

NRC. 2001. Nutrient Requirements of Dairy Cattle. Natl. Acad. Press, Washington, DC.

O'Driscoll, K., D. Gleeson, B. O'Brien, and L. Boyle. 2010a. Effect of milking frequency and nutritional level on hoof health, locomotion score and lying behaviour of dairy cows. Livest. Sci. 127:248-256.

O'Driscoll, K., B. O'Brien, D. Gleeson, and L. Boyle. 2010b. Milking frequency and nutritional level affect grazing behaviour of dairy cows: A case study. Appl. Anim. Behav. Sci. 122:77-83.

Patton, J., D. A. Kenny, J. F. Mee, F. P. O'Mara, D. C. Wathes, M. Cook, and J. J. Murphy. 2006. Effect of milking frequency and diet on milk production, energy balance, and reproduction in dairy cows. J. Dairy Sci. 89:1478-1487.

Peeler, E. J., M. J. Green, J. L. Fitzpatrick, K. L. Morgan, and L. E. Green. 2000. Risk factors associated with clinical mastitis in low somatic cell count British dairy herds. J. Dairy Sci. 83:2464-2472.

Sapru, A., D. M. Barbano, J. J. Yun, L. R. Klei, P. A. Oltenacu, and D. K. Bandler. 1997. Cheddar cheese: Influence of milking frequency and stage of lactation on composition and yield. J. Dairy Sci. 80:437-446.
SAS Institute. 2009. SAS User's Guide. SAS Institute Inc., Cary, NC.

Schirmann, K., N. Chapinal, D. M. Weary, W. Heuwieser, and M. A. G. von Keyserlingk. 2012. Rumination and its relationship to feeding and lying behavior in Holstein dairy cows. J. Dairy Sci. 95:3212-3217.

Schirmann, K., M. A. G. von Keyserlingk, D. M. Weary, D. M. Veira, and W. Heuwieser. 2009. Technical note: Validation of a system for monitoring rumination in dairy cows. J. Dairy Sci. 92:6052-6055.

Shabi, Z., I. Bruckental, S. Zamwell, H. Tagari, and A. Arieli. 1999 Effects of extrusion of grain and feeding frequency on rumen fermentation, nutrient digestibility, and milk yield and composition in dairy cows. J. Dairy Sci. 82:1252-1260.

Smith, J. W., L. O. Ely, W. M. Graves, and W. D. Gilson. 2002. Effect of milking frequency on DHI performance measures. J. Dairy Sci. 85:3526-3533.

Tucker, C. B., D. E. Dalley, J.-L. K. Burke, and D. A. Clark. 2007. Milking cows once daily influences behavior and udder firmness at peak and mid lactation. J. Dairy Sci. 90:1692-1703.

Tyler, J. W., L. K. Fox, S. M. Parish, J. Swain, D. L. Johnson, H. A. Grasseschi, and R. Gant. 1997. Effect of feed availability on postmilking standing time in dairy cows. J. Dairy Res. 64:617-620.

Tyrrell, H. F., and J. T. Reid. 1965. Prediction of the energy value of cow's milk. J. Dairy Sci. 48:1215-1223.

Van Soest, P. J., J. B. Robertson, and B. A. Lewis. 1991. Methods for dietary fiber, neutral detergent fiber and nonstarch polysaccharides in relation to animal nutrition. J. Dairy Sci. 74:3583-3597.

Varner, M., S. Hale, T. Capuco, A. Sanders, and R. Erdman. 2002 Increasing milking frequency. Adv. Dairy Technol. 14:265-271. 